\title{
Comentário sobre os encontros de Ulysses Vianna Filho com Franco Basaglia
}

\section{Introdução}

Vinte anos separam a morte do ilustre professor italiano de psiquiatria Franco Basaglia da do nosso eminente professor brasileiro de psiquiatria Ulysses Vianna Filho.

Como editor científico e autor da apresentação de um livro esgotado no Brasil, em todas as suas edições, ${ }^{1}$ e que foi relançado em primeira edição italiana no ano de 2000 , como parte das comemorações à memória de Basaglia, sinto-me, nesse mesmo ano em que perdemos Vianna Filho, motivado a relembrar, ainda que fragmentos, os debates estabelecidos entre ambos, provavelmente pouco conhecidos pela comunidade psiquiátrica brasileira.

\section{O encontro}

Franco Basaglia e Ulysses Vianna Filho debateram no Rio de Janeiro* e em Belo Horizonte.** Vamos destacar alguns pontos altos desse extraordinário debate:

Vianna Filho: “(...) Não defendemos o modelo repressor da psiquiatria. Defendemos o outro modelo, e quando o prof. Basaglia diz que devemos defender o homem nos seus três aspectos (bio-psico-social), é isso que fazemos (na Associação Brasileira de Psiquiatria)."

Basaglia: “(...) Estou de acordo com o professor. Acho que no Brasil existe um despontar na vontade de mudança. Permitome sugerir que seria necessário que a Associação Brasileira de Psiquiatria apoiasse todas as tentativas de mudança, dando cobertura técnica e científica a essa mudança."

Vianna Filho: “(...) É este o desafio que assumimos na direção da ABP. Sentimos que devemos mudar o comportamento dos psiquiatras frente aos doentes mentais. Essa foi a posição que defendemos oficialmente no Congresso de Camboriú, quando assumimos o compromisso de reformar a assistência psiquiátrica, transformá-la numa assistência para atendimento da população e não numa assistência elitista."

Basaglia: “(...) Há um pessimismo incrível com relação ao nosso trabalho (assistência psiquiátrica), que é o pessimismo da razão. No lugar do pessimismo da razão nós propomos o otimismo da prática."
Vianna Filho: “(...) Creio que foi esse pessimismo que levou a todos os movimentos 'antis' que eclodiram na década de 60: antipsiquiatria, antipsicanálise, anticiência, antiliteratura... A meu ver, isto representa uma crise do racionalismo do século $\mathrm{XX}$, essa crise que, no seu excesso, levou o mundo a duas guerras mundiais."

Basaglia: “(...) Eu aproveito para precisar, e tenho testemunhas presentes, que jamais falei de 'anti'. Eu não sou um antipsiquiatra porque esse é um tipo de intelectual que eu rejeito. Eu sou um psiquiatra que quer dar ao paciente uma resposta alternativa àquela que foi dada até agora."

\section{Uma breve reflexão}

Esse curto diálogo entre Basaglia e Ulysses me faz recordar a frase predileta da minha querida mestre em história, Helena Pignatari Werner: "Povo sem memória, povo sem história."

É dessa falta de memória, geradora da impossibilidade de construir a verdade histórica, que se sustentam movimentos 'antis' e movimentos 'prós' manicomiais. Para seus militantes, Ulysses não passa de um conservador e Basaglia, de um antipsiquiatra. Ainda bem que atualmente os psiquiatras e outros profissionais de saúde mental no Brasil me parecem cada vez mais distantes desses radicalismos, e é justamente nesse ponto que residem as nossas esperanças de uma profunda reformulação na política brasileira de saúde mental e, conseqüentemente, no surgimento de novos modelos assistenciais em psiquiatria.

Gabriel R Figueiredo Faculdade de Ciências Médicas da Pontifícia Universidade Católica de Campinas

\section{Referências}

1. Basaglia F. A psiquiatria alternativa: conferências no Brasil. São Paulo (SP): Brasil Debates; 1979. 